\title{
The Application of Indonesian Spelling and Standard Vocabulary on Facebook: Case Study on the National Political Store
}

\author{
Winda Azmi, Ermanto, Harris Effendi Thahar \\ Universitas Negeri Padang \\ Email: windaazmy1991@gmail.com, ermanto@fbs.unp.ac.id
}

\begin{abstract}
This study was aim to determine the accuracy and inaccuracy of the use of Indonesian spelling and standard vocabulary in facebook posting Elviana one of the national political figures. The data in this research were written words, words, phrases, clauses, and sentences, both Indonesian, regional, and foreign. The source of this research data was the status uploaded in facebook Elviana one of the national political figures. The results of this study found the accuracy and inaccuracy of the use of Indonesian spelling and the use of standard vocabulary. First, the use of Indonesian spelling. From one hundred and thirty data studied found one hundred and twenty incorect data and ten precise data. The inacurate was made up of letters, words, friendly. Second, the use of standard vocabulary. From one hundred and thirty data studied found forty seven incorrect data and fifty six praise data used of standard vocabulary. The inaccuracy consists of Indonesian vocabulary, vocabulary, language, and Indonesian vocabulary. Thus, it can be concluded the status written by one of the national figures, Elvina, on the dominant spelling syndrome was not appropriate. In situations vocabulary/diction status was written predominantly precise.
\end{abstract}

Keywords-application; spelling; vocabulary; facebook

\section{INTRODUCTION}

Facebook or FB is a social networking service that was launched in February 2004. Facebook is a Web that is used to communicate with various features that provide various convenience in communication (Nurcholis, 2013). The feature has given facebook in order to. Every facebook user has the freedom to deliver what they want in status updates.

On the status on facebook, the author uses a variety of vocabulary. Vocabulary used in the form of spelling vovabulary and standard vocabulary. Alwi $(2003$, p.30) said that in the official situation and unofficial situation should use standard language. Educated societies very often use Indonesian verbs. Most societies, such as students, students, staff, teachers, lecturers, lawyers, executive officers, legislators, and law enforcement officials always use Indonesian verbs. In order to be an authoritative State organizer, it is appropriate to use Indonesian written and proper writing (Ermanto, 2018, p.29-30).

The standard language supports four functions, namely the unifying function, the giver functionality, the authoritative carrier function, and the reference frame function. The function becomes a measure to know the use of one's language (Alwi, 2003, p.30). Writing status on facebook found many spelling mistakes due to the use of varied language. The author of the message is not paying enough attention to the correct language method so that it is ignored. In relation to the spelling, Safitri $(2015$, p.12) divides the spelling into two, spelling in terms of general and special terms. The general terms mean the entire provisions governing the symbolic language sound, including the separator and its incorporation, and supplemented by the use of punctuation. While a special aspect, spelling can be interpreted as a vowel of language sounds with letters, either in the form of the letter by letter or letters that have been arranged into words, groups of words or sentences.

Based on the undangan-undang republik Indonesia number 24 regulation on language in 2009, it is mentioned that it is mandatory to use good and correct Indonesian language (UU RI, 2009). That is, every citizen of Indonesia must use good and correct Indonesian. Especially among the officials who become role models for the community. Should, in writing or express something should be guided by spelling Indonesian language is good and true. Rules must be applied and applied in everyday life.

The use of Indonesian spelling in the writing of students in Indonesia is not an appropriate use. The inaccuracy is found in previous research (Ariningsih, 2012; Dina, 2015; \& Supriadin, 2016). In the research found the most dominant inaccuracy is the use of Indonesian spelling. This is because students pay less attention to the rules of writing in accordance with the Pedoman Umum Ejaan Bahasa Indonesi (PUEBI). Similarly, research on official mail. The inappropriateness of the dominant service letters on the use of Indonesian spelling there were studies (Saragi, 2008; Darmasuti, 2009; Heni, 2014; \& Purwandari, 2014). The inaccuracy of spelling in the study is due to lack of accuracy in the writing of the official letter.

Research related to Indonesian spelling and standard language vocabulary has been done by Erlinawati, et al. (2017) on social networking status of facebook student STMIK Duta Bangsa Surakarta. The results of this study say that there are nine language errors and 5 status is in accordance with the language. The language error is seen in the 
following aspects: 1) punctuation, 2) letter writing, 3) capital letters, 4) word choice (diction), 5) foreign or regional use, 6) standard words, 7) word abbreviations, 8) particle writing, and 9) front-end writing. The same is also done by Prasetiyo (2013) on the official script at the Office of Village Temulus, Kecamatan Mejobo, Kabupaten Kudus. This study finds the use of Improper Spellings imprecise. Such inaccuracies include errors: 1) the use of capital letters, 2) the use of italics, 3 ) the use of periods (.), 4) the use of commas (,), 5) abbreviation (acronyms), 6) numerical writing and number symbol, 7) use of the underscore, 8) the use of hyphens (-), 9) derivation of words, 10) the use of slashes, and $11)$ the use of parentheses $((\ldots))$.

Furthermore, Astuti (2013) conducts research related to Indonesian spelling and standard vocabulary in the rubric of "Opinion" of Pendapa Tamansiswa magazine. The study found two inaccuracies in the use of word and spelling options. First, the inaccuracy of word choice and word choice mismatch. Second, the imprecision of spelling implementation includes (1) improper use of letters, (2) inaccurate wording, (3) improper use of punctuation, and (4) inaccurate writing of absorption elements. Corral (2017) also conducted a mistake study in applying grammar on a facebook post of Sorsogon National High School student, Philippines. The study found three errors in the Facebook post, among others (1) The students made mistakes in grammar and usage on the use of Verb-tense, the use of SubjectVerb and the use of prepositions, (2) the students made mistakes in the use of verbs and the use of words (3) lack of reinforcement materials and other intervention exercises in student learning related grammar rules. Akampirige and Benjamin (2014) conducted a study on the misuse of punctuation on students of Polytechnic of Ghana, Africa. From this research, it is learned that Polytechnic Students in Ghana still have difficulty identifying punctuation in written text and using proper punctuation in student writing.

Based on the above description, the issues to be studied in this article is the application of the use of Indonesian spelling and standard vocabulary in the status of Elviana facebook one of the national political figures. The difference of this study with previous research is in the object. This study looks at how a national political figure wrote the status on facebook, whether it is according to the rules of Indonesian spelling and raw vocabulary. The purpose of this assessment is viewed from two aspects, namely the use of Indonesian spelling and the use of standard vocabulary. The use of Indonesian spelling is focused on the use of letters, the use of words, and the use of punctuation. As for the use of standard vocabulary is focused on the standard vocabulary of Indonesia, standard foreign language vocabulary, and standard vocabulary of regional languages.

\section{METHODS}

This research used the descriptive qualitative method because this research aimed to explain the deep phenomenon through deep data collection (Kriyantono, 2008). The data in this research were written speech that is word, phrase, clause, and sentence, either in Indonesian, regional, or foreign language. The source of this research data was the status uploaded in facebook by Elviana, one of the national political figures. The data were collected from JulyNovember 2017.

Sudaryanto (1993, p.5-7) suggests that there three main stages in conducting language research, namely: (1) the stage of providing data; (2) data analysis stage, and (3) presentation stage of the result of data analysis. The research procedure used is based on the above three stages. First, the stage of data provision is the first step in doing research by providing sufficient data. The data provided in this study as many as 130 data from 45 screenshots status. Second, the data analysis phase. The data analysis explains the word contained in the sentence so that it has a precise and unambiguous meaning (Mastoyo, 2007, p.47). Data were analyzed in accordance with the objectives of the study, namely to determine the accuracy and inaccuracy of the use of Indonesian spelling and raw vocabulary. Data analysis is done in two ways. First, identify and transcribe data from facebook status. The two, classify the data based on the use of Indonesian spelling and standard vocabulary. Third, the presentation stage. The presentation stage of data analysis is the last step in the research. The data that have been analyzed and then elaborated in detail in the form of sentences.

\section{FINDING AND DISCUSSION}

There are two things that will be discussed in this research. First, the use of Indonesian spelling includes the incorrectness of writing letters, inaccurate wording, inaccurate use of punctuation, and the accuracy of the use of Indonesian spelling. Second, the use of standard vocabulary includes the inaccuracy of standard Indonesian vocabulary, inaccurate foreign language vocabulary, inaccurate standard vocabulary of regional languages, and the accuracy of the use of standard vocabulary.

\section{Use of Indonesian Spelling}

In facebook status that has been analyzed, there are four parts of spelling used. Among the inaccuracy of writing letters, improper use of words, inaccurate use of punctuation, and the accuracy of the use of Indonesian spelling. The following will explain the four parts.

1. Inaccurate Use of Letters

Based on the analyzes that have been done, there is an inaccuracy of writing capital letters as many as 54 data. The inaccuracy can be seen in the following example. 
(1) Semoga dibawah kepemimpinan Rektor baru, bisa mempercepat Undhari mencapai kejayaanny).

(2) Rame niaaaan......Yg penting hari ini riang gembira bersama warga dusun Sungai Lilin.

(3) RAKER KOMISI XI DPRRI dg Kementrian PPN/Kepala Bapenas Rabu 13 Sept 2018

In example (1) there is an inaccurate capital letter writing in the first letter of the name of the office. Based on the Ejaan Bahasa Indonesia (2017), the first letter of the name of the title shall be capitalized if it is followed by the name of the person or institution concerned. The letter $\mathrm{R}$ on the word of the rector should not be capitalized because it is not followed by the person's name or the name of the agency. In example (2) it is found that the incorrectness of capital letter writing in the first letter of the geographical name. The first letter of the geographic name is capitalized when the geographical name is followed. In example (3) there is an inaccurate capital letter writing on the first letter of the acronym of the self. The acronym of the self-name is capitalized when it is a composite syllable or a combination of letters and syllables of the word series (Ejaan Bahasa Indonesia, 2017). Examples of the above sentences can be fixed below.

(1a) Semoga di bawah kepemimpinan rektor baru, bisa mempercepat UNDHARI mencapai kejayaannya.

(2a) Ramai nian, yang penting hari ini riang gembira bersama warga Dusun Sungai Lilin.

(3a) Raker komisi XI DPRRI dengan Kementrian PPN/Kepala Bapenas, Rabu, 13 September 2018.

In line with the results of these studies, Erlinawati, et al. (2017) states that in social networking facebook status STMIK Duta Bangsa Surakarta also there is a mistake of writing letters. Both of these studies have an equation of inaccuracy in capital letter writing.

\section{Inaccurate Use of Words}

In analyzing it has been done there is the inaccurate use of the word repeated, forewords, abbreviations and acronyms, and numbers and numbers. First, the inappropriateness of using the repeated word is 9 data. Second, the imprecision of the use of the preposition word is 3 data. Third, the inaccuracy of abbreviations and acronyms is 91 data. Fourth, the inaccuracy of the use of numbers and numbers there are 17 data. The inaccuracy can be seen in the following example.

(4) Saluuut dg anak2 santrinya.

(5) Semoga dibawah kepemimpinan Rektor baru, bisa mempercepat Undhari mencapai kejayaannya.

(6) Mulai dr batik, keripik pisang, kopi, jahe, dll.

(7) $\mathbf{1 4}$ jam penerbangan.

In Example (4) there is an inappropriateness of reusing the word anak2. The use of a re-word should use a hyphen between the two words. In example (5) there is an imprecision of the use of the proposition. Based on the Ejaan Bahasa Indonesia (2017), the use of the preposition word in, to, and from is written separately from the word that follows it, except in a combination of commonly regarded words as one word as to and rather than. In example (6) there is an inaccuracy in the use of abbreviations and acronyms. The use of abbreviations is used for person name abbreviations, title names, greetings, titles, or rank followed by periods and abbreviations are also used for common abbreviations such as dll., dsb., and hlm., (Ejaan Bahasa Indonesia, 2017). In Example (7) there is an inaccuracy in the use of the word numbers and numbers. The use of the number symbol on the sentence is not appropriate because the number symbol at the beginning of the sentence is written with letters. If necessary, the order of sentences is changed so that numbers that can not be declared with one or two words are not present at the beginning of the sentence (Ejaan Bahasa Indonesia, 2017). Examples of the above sentences can be fixed below.

(4a) Salut dengan anak-anak santrinya.

(5a) Semoga di bawah kepemimpinan Rektor baru, bisa mempercepat UNDHARI mencapai kejayaannya.

(6a) Mulai dari batik, keripik pisang, kopi, jahe, dll.

(7a) Penerbangan selama empat belas jam.

It is also found in research Prasetyo, et al. (2013) which states that there is an inaccurate wording in the official script at the Temulus Village Office, Kudus District. Such inaccuracies are seen only in abbreviation (acronyms) and numerical and numeric symbols.

\section{Inaccurate Use of Punctuation}

In the analyzes that have been done, there are errors in the use of point punctuation, commas, colons, question marks, exclamation marks, brackets, and quotation marks. First, the misuse of point punctuation is 22 data. Second, there are 12 data coma misuse errors. Thirdly, the error of using colon marks is 1 data. Fourth, the error of using question marks there are 3 data. Sixth, misuse of quotes. two have 1 data. Seventh, the error of using parentheses there are 3 data. The inaccuracy can be seen in the following example.

(8) Komisi XI DPR bersama Dirjen Anggaran Kementrian Keuangan RI... 
(9) Biasanya foto2 dulu apalagi kalau ruangan msh sepi, banyak kursi msh kosong.

(10) Target : di semua ibukota kecamatan se Prov Jambi ada kantor Bank.

In Example (8) there is an inaccurate use of the dot at the end of the sentence. Meanwhile, according to Ejaan Bahasa Indonesia, (2017), the dot is always used at the end of a sentence that is not a question or a call. So, in the above sentence, it should use a dot at the end of the sentence. Example (9) there is an inaccuracy of the use of a comma. Comes should be used after the first word because the comma is used to avoid misreading behind the information contained at the beginning of the sentence (Ejaan Bahasa Indonesia, 2017). In Example (10) there is an inaccuracy of the use of punctuation. The inaccuracy is because the above sentence is not a complete statement. The use of a colon may be used at the end of a full statement if followed by a series or details (Ejaan Bahasa Indonesia, 2017). Examples of the above sentences can be fixed below.

(8a) Komisi XI DPR bersama Dirjen Anggaran Kementrian Keuangan RI.

(9a) Biasanya foto-foto dulu, apalagi kalau ruangan msh sepi, banyak kursi masih kosong.

(10a) Target di semua ibukota kecamatan se-Provinsi Jambi ada kantor Bank.

Inaccurate use of punctuation is also found in the research of Rahmat (2017) which states that there is the inaccurate use of comma punctuation in Magazine Makassar Terkini. Research Grace (2017) focuses only on the ineffectiveness of sentences, coma use errors and sentence structure errors. The difference with this research lies in the type of punctuation found. Punctuation found in this study there are seven kinds, while the punctuation used in research Grace found two kinds of punctuation.

\section{Accuracy of Use of Indonesian Spelling}

In analyzing the data there is the accuracy of the use of Indonesian spelling of 10 data. The precision can be seen in the following example.

(11) Pesta perkawinan keponakan kandung Radiah \& Roby.

(12) Negara ini aslinya kaya raya, alamnya subur.

In examples (11) and (12) have used the Indonesian spelling appropriately. This is seen in example (11) using capital letters correctly. Based on Ejaan Bahasa Indonesian (2017), capital letters are used when the first element of a person's name. While for example (12) has been using a comma correctly. A comma is used when separating the information contained at the beginning of a sentence. This is also found in the research of Erlinawati, et al. (2017) which states that there is precisely the use of Indonesian spelling on social networking status of facebook students STMIK Duta Bangsa Surakarta. Accuracy is contained as many as 5 statuses of 19 status under study.

\section{Use of Standard Indonesian Vocabulary}

The use of standard vocabulary on the status of facebook that has been analyzed, there is inaccuracy in the standard Indonesian vocabulary, foreign standard vocabulary, and the standard vocabulary of the Region. The following will explain the inaccuracy of the raw vocabulary.

1. Inaccurate Vocabulary Not Raw Indonesian

In the analysis, there is an inaccuracy of the use of standard Indonesian vocabulary. The Inaccuracy of Indonesian vocabulary is 29 data. Based on these data can be seen the following example.

(13) Cantik, alim, kaya, mengelola lembaga tahfisz Alquran.

In example (13) there is an inappropriate use of standard Indonesian vocabulary. Seen on the use of the word tahfisz. Based on Kamus Besar Bahasa Indonesia (2016) the word tahfisz standard is tahfiz. Examples of the above sentences can be fixed below.

(13a) Cantik, alim, kaya, mengelola lembaga tahfiz Alquran.

\section{Inaccurate Foreign Language Vocabulary}

In analyzing there is the inaccurate use of foreign vocabulary in the Foreign language. Inaccurate foreign language vocabulary there are 13 data. Based on these data can be seen the following example.

(14) Team panja sangat hati2 jgn sampai semakin membebani rakyat.

In example (14) there is an inappropriate use of standard Indonesian vocabulary. The inaccuracy is seen in the word Team. Based on Kamus Besar Bahasa Indonesia (2016) the standard vocabulary of Foreign Language Team is Tim. Examples of the above sentences can be fixed below.

(14a) Tim panja sangat hati-hati jangan sampai semakin membebani rakyat.

3. Inaccurate Vocabulary of Regional Language Standard

In analyzing there is an inaccuracy of using the standard vocabulary of the Regional Language. Inaccuracy there are 6 data. Based on these data can be seen the following example.

(15) Ado benang di dalam lumpur, Benang untuk pengikat ubi, Hari ini senang nian hati rakyat Limbur, Kareno sdh punyo kantor Bank Jambi. 
In example (15) there is an inaccurate use of the standard vocabulary of the Regional language. The inaccuracy is seen in the words of Ado and Kareno. Based on the Big Indonesian Dictionary the standard word of Ada and Karena (Kamus Besar Bahasa Indonesia, 2016). Examples of the above sentences can be fixed below.

(15a) Ada benang di dalam lumpur, Benang untuk pengikat ubi, Hari ini senang nian hati rakyat Limbur, Karena sdh punyo kantor Bank Jambi.

In line with the results of this study, Erlinawati, et al. (2017) also stated that there is an inappropriate use of standard vocabulary on social networking facebook status STMIK Duta Bangsa Surakarta students. The inaccuracy is seen in three aspects, namely the use of standard Indonesian vocabulary, standard foreign language vocabulary, and standard vocabulary of regional languages.

4. Accuracy of Standard Vocabulary Usage

In the analysis there is a precise use of standard vocabulary. The accuracy there are as many as 55 data. Based on these data can be seen the following example.

(16) Semoga berbahagia.

(17) Kota Muara Bungo sekarang sudah menjadi kota alternatif untuk menggelar acara yang dihadiri pejabat pusat.

In Example (16) it is appropriate to use standard Indonesian vocabulary. Based on Kamus Besar Bahasa Indonesia edition V (2016), the standard vocabulary is correct if it is included in KBBI. In example (17) it is also appropriate to use the foreign language vocabulary. The alternative word is standard based on KBBI.

\section{CONCLUSION}

Based on the above description can be concluded that found the accuracy and inaccuracy of the use of Indonesian spelling and the use of standard vocabulary. First, the use of Indonesian spelling. Of the 130 data studied found 120 incorrect data and 10 precise data. The inaccuracy consists of letter writing, word usage, and punctuation. Second, the use of standard vocabulary. Of the 130 data studied found 47 incorrect data and 56 precise data use of standard vocabulary. Such inaccuracies consist of standard Indonesian vocabulary, foreign language vocabulary, and standard vocabulary of regional languages. Thus, it can be concluded that the status written by one of the national figures, Elvina, on writing dominant spelling is not appropriate. While the writing vocabulary/diction of the written status tends to be right.

For one of the national figures, should use spelling and standard vocabulary according to Indonesian rules in a facebook post. Under Law number 29 every citizen of Indonesia must use and apply good and correct Indonesian language in everyday life. Therefore, both in facebook postings and in other matters must use the Indonesian language correctly and appropriately.

\section{References}

Alwi, H. (2003). Tata bahasa baku bahasa indonesia. Jakarta: Balai Pustaka.

Akampirige A. O. M., \& Benjamin A. (2014). Errors in the use of punctuation marks among polytechnic students. International Journal of English Language and Literature Studies, 3(1), 93-98.

Ariningsih, N. E., Sumarwati, \& Saddhono, K. (2012). Analisis kesalahan berbahasa Indonesia dalam karangan eksposisi siswa Sekolah Menengah Atas. Jurnal BASASTRA, 1(1), 40-53.

Astuti,Y. D., \& Mukhlish. (2013). Ketidakefektifan kalimat dalam rubrik “opini” majalah Pendapa Tamansiswa. Jurnal CARAKA, 4(1), 92-110.

Badan Pengembangan dan Pembinaan Bahasa Republik Indonesia. (2017). Pedoman umum ejaan bahasa Indonesia (PUEBI). Jakarta: Ilmu.

Corral, J. C. D. (2017). Facebook posts: error analysis on english grammar and usage. Jurnal Asian Journal of Educational Research, 5(3), 112-140.

Erlinawati, M., \& Yuliana M. E. (2017). Analisis sosiolinguistik kesalahan berbahasa pada jejaring sosial status facebook (studi kasus mahasiswa STMIK Duta Bangsa Surakarta. Jural Magistra, (100), 20-25.

Ermanto dan Emidar. (2018). Bahasa Indonesia: pengembangan kepribadian di perguruan tinggi. Jakarta: Rajagrafindo Persada.

Darmasuti, F. D. (2009). Analisis kesalahan berbahasa dalam surat dinas kantor Kelurahan Ngolodono Karangdowo Klaten. Skripsi. FKIP Universitas Muhammadiyah Surakarta: Surakarta.

Dina, R. (2015). Penggunaan kalimat efektif dalam karya ilmiah siswa: aplikasi semantik studi kasus siswa kelas XI SMK Negeri 2 Lembah Gumanti. Jurnal Gramatika, 1(i2), 167-173.

Heni, S. P. (2014). Analisis Kesalahan berbahasa Indonesia pada surat dinas kantor Kepala Desa Jladri. Jurnal BASASTRA, I(3), 478-489.

Kriyantono, R. (2008). Teknik praktis riset komunikasi. Jakarta: Kencana Prenada Media Group. 
Mastoyo. (2007). Pengantar Metode Penelitian Bahasa. Yogyakarta: Carasyatibooks.

Nurcholis, M. (2013). Variasi bahasa, singkatan, dan kesalahan ejaan pada status dan coment teman di facebook. Naskah Publikasi. Surakarta. Universitas Muhammadiyah Surakarta

Prasetiyo, E. (2013). Penggunaan kalimat efektif dan ejaan yang disempurnakan dalam naskah dinas di kantor Desa Temulus, Kecamatan Mejobo, Kabupaten Kudus. Naskah Publikasi. Surakarta. Universitas Muhammadiyah Surakarta.

Rahmat. (2017). Ketidakefektifan ragam bahasa jurnalistik majalah makassar terkini. Jurnal Pendidikan Edumaspul, 1(1), 14-23.

Safitri, L. W. (2016). Pedoman ejaan bahasa Indonesia. Yogyakarta: Pusat Kajian Bahasa.

Saragi, R. (2008). Tinjauan efektivitas penggunaan bahasa indonesia yang baik dan benar dalam surat dinas. Jurnal Mitra, XIV (2).

Sudaryanto. (1993). Metode dan aneka teknik analisis bahasa: pengantar penelitian wahana kebudayaan. Yogyakarta: Duta Wacana University Press.

Supriadin. (2016). Identifikasi penggunaan kosakata baku dalam wacana bahasa indonesia pada siswa kelas VII di SMP Negeri 1 Wera Kabupaten Bima tahun pelajaran 2013/2014. Jurnal Ilmiah Mandala Education, 2(2), 151-161.

UU RI. (2009). Undang-undang republik Indonesia nomor 24 tahun 2009 tentang bendera, bahasa, dan lambang Negara, serta lagu kebangsaan. Jakarta. 